\title{
SERIAL DYREKTORZY. DZIEJE PRAWNEGO UNORMOWANIA STATUSU DYREKTORA
}

\author{
Abstract \\ DYREKTORZY TV SERIES. THE HISTORY OF THE LEGAL STATUS \\ OF A MANAGER
}

In journalistic publications about cultural policy, there is a prevailing conviction that the system change of 1989 put an end to the prosperity and carefreeness of Polish theaters and made managers of these institutions face many new problems, unknown in the days of communism. In this paper, based on the study of community efforts to strengthen the position of theater managers in relations with authorities, I argue that this view is overly simplistic and idealizes the situation of culture in the communist Poland.

The prolonged and complex efforts to determine the rules of theater manager's work - which took more than fifty years (1958-2011) - are like a television “soap opera." Hence the paper's title (loosely) alluding to the Polish TV show Dyrektorzy, popular in 1970s, which portrays managers of the socialist industry, although the paper does not contain as many dramatic turns of events.

The analysis of the sources shows the unchanging ills of the Polish theatre life, which moved from socialism to capitalism, from dictatorship to democracy. Theatre managers are still forced to negotiate with authorities.

SŁOWA KLUCZE: instytucja artystyczna, zarządzanie publiczną instytucją kultury, dyrektor, konkurs na dyrektora instytucji kultury, teatr, opera, sztuki widowiskowe

KEY WORDS: artistic institution, management of public cultural institution, manager, appointment of cultural institution manager following competition, theater, opera, performing arts

W publicystycznych ujęciach polityki kulturalnej dominuje przekonanie, że zmiana ustrojowa roku 1989 była momentem, w którym zakończył się okres dobrobytu i beztroski polskich teatrów, natomiast dyrektorzy tych instytucji stanęli przed wieloma nowymi problemami, nieznanymi w czasach PRL-u. W tym artykule - na podstawie badania środowiskowych starań o umocnienie pozycji dyrektora teatru 
w relacjach z władzami - dowodzę, że to pogląd upraszczający, do tego idealizujący sytuację kultury w Polsce Ludowej.

Długotrwałe i pełne komplikacji starania o określenie zasad funkcjonowania dyrektorów teatrów - które zajęly ponad pięćdziesiąt lat (1958-2011) - przypominają telewizyjny „tasiemiec”. Stąd tytuł artykułu nawiązujący (luźno) do popularnego w latach siedemdziesiątych serialu Dyrektorzy, portretującego menedżerów socjalistycznego przemysłu. Choć trzeba zastrzec, że w artykule będzie mniej dramatycznych zwrotów akcji.

Analiza źródeł pokazuje niezmienność bolączek polskiego życia teatralnego, które z socjalizmu przeniosły się do kapitalizmu, z dyktatury do demokracji. W tych sprawach wciąż na nowo podejmowane są przez dyrektorów teatrów negocjacje z władzami.

\section{Pierwsze projekty}

Na fali zmian politycznych po październiku 1956 roku władze zdecydowały się przeprowadzić decentralizację zarządzania kulturą, m.in. teatry zostały przekazane terenowym organom administracji państwowej - radom narodowym. Środowisko teatru liczyło, że ten proces będzie miał głęboki wymiar i pozwoli zwiększyć autonomię instytucji. Jednym $\mathrm{z}$ warunków powodzenia tego planu było uporząakowanie zasad funkcjonowania dyrektora teatru, najlepiej w formie oficjalnie przyjętego dokumentu pod nazwą Status dyrektora teatru. Pierwsze postulaty w tej sprawie pojawiły się na przełomie roku 1957 i 1958. Najpierw w dyskusjach środowiskowych, później w prasie i na spotkaniach z władzami. Była to reakcja na sposób traktowania funkcji dyrektora $\mathrm{w}$ okresie stalinizmu i ścisłej centralizacji zarządzania. Niemal wszystkie sprawy - planowanie repertuaru, dobór zespołu artystycznego, gospodarka finansowa - były w gestii Centralnej Dyrekcji Teatrów przy MKiS, dyrektorom pozostawało bieżące administrowanie.

O przygotowanie Statusu bardzo aktywnie apelowali dyrektorzy teatrów - co nie dziwi - choć zapobiegliwie stawiali problem w szerokim kontekście zaniechań ze strony władz. Podczas narady dyrektorów (5-6 maja 1958 roku) dyrektor stołecznego Teatru Powszechnego, Tadeusz Kazimierski, zwracał uwagę, że wciąż brakuje kompletu - ważnych dla funkcjonowania teatrów - dokumentów: nie ma statutów przedsiębiorstw, nie ma statusu dyrektora, a regulaminy pracy wprowadzono tylko w części teatrów czy oper ${ }^{1}$. Podczas narady pojawiły się konkretne postulaty dotyczące sytuacji dyrektora: trzyletnia kadencja, wyższe uposażenia kierowników teatrów (jak dowodzono, kształtowały się one poniżej „bardzo średnich zarobków aktora na średnim poziomie"), zwiększenie uprawnień do zawierania umów z realizatorami przedstawień ${ }^{2}$.

1 Stenogram z narady dyrektorów teatrów 5-6 maja 1958 r., AZASP 3/169, s. 71-72.

2 Tamże, s. 83-84, 169-170. 
Dwa tygodnie później (21 maja 1958 roku) odbyła się konferencja z udziałem przedstawicieli Centralnego Zarządu Teatrów z przedstawicielami prezydium ZASP oraz Zarządu Sekcji Kierowników Teatrów. Na spotkaniu omawiano kwestie związane $\mathrm{z}$ trybem powoływania dyrektorów, zasady wynagradzania oraz kontrakty dyrektorskie. Zgodnie sformułowano postulat, by powoływaniu dyrektora towarzyszyły trzy dokumenty: 1. Pismo odpowiednich władz powołujące dyrektora. 2. Pismo tej samej władzy, w którym ujęto by wszelkie sprawy uzgodnione przez strony (np. charakter teatru, liczba scen, zasięg terenowy, sprawy finansowe, inwestycyjne, remontowe i mieszkaniowe). 3. Umowa o pracę3. Dziesięć dni później SPATiF-ZASP zaproponował treść umowy z dyrektorem oraz nawet projekt pisma okólnego Ministra Kultury i Sztuki w sprawie zasad powoływania i wynagradzania dyrektorów teatrów. Wśród zasad proponowano m.in., by dyrektor teatru był jednocześnie kierownikiem artystycznym oraz by rada narodowa powoływała dyrektora za zgodą MKiS i po zasięgnięciu opinii ZASP'.

Po tych intensywnych pracach zapadła cisza do jesieni. Przerwał ją Zarząd Główny SPATiF, podejmując uchwałę apelującą do ministra Galińskiego o jak najszybsze uporządkowanie sytuacji prawnej teatrów. Uchwała Zarządu Głównego ZASP z 29 września 1958 roku była krótka:

Plenum z przykrością stwierdza, że - mimo wielokrotnych interwencji ze strony Stowarzyszenia - uzgodnione $\mathrm{z}$ Centralnymi Zarząami na specjalnej naradzie w maju br. zmiany przestarzałych przepisów o gospodarce teatralnej, podobnie jak zmiany w systemie norm, projekty kontraktów aktorskich oraz projekty umów o pracę z dyrektorami, nie zostały dotychczas wprowadzone w życie.

Uchwałę przedrukował „Teatr”, publikując ją we wstępniaku pod mocnym tytułem: Dlużej zwlekać nie podobna 5 .

Reakcją MKiS były dwa dalsze spotkania robocze, na których ostatecznie uzgodniono trzecią redakcję pisma okólnego „W sprawie zasad powoływania i wynagrodzenia dyrektorów, kierowników artystycznych oraz zastępców dyrektorów teatru". Następnie materiał przekazano Departamentowi Ekonomicznemu MKiS, gdzie utknął, ponieważ nie widziano możliwości uzgodnienia jego ostatecznego kształtu. To typowe resortowe zderzenie - negocjacje prowadził organ ministerstwa, odpowiedzialny merytorycznie i działowo, a zdanie rozstrzygające miały tzw. departamenty funkcjonalne: ekonomiczny lub prawny, które rządziły się swoimi regułami. Ich ustalenia nie podlegały negocjacjom nawet w ramach rozmów między departamentami.

Po roku, w listopadzie 1959 roku, pismo „Teatr” upomniało się o status dyrektora teatru, przypominając naradę dyrektorów z maja 1958 roku oraz postulaty - unormowanie statusu dyrektora i przedłużenie objętej umową kadencji dyrektora z jednego roku na trzy lata. „Od tego czasu upłynęło wiele miesięcy - pisał Edward Csató,

3 Odpis pisma 1596/58 Prezydium ZASP do CZT i CZIM z dnia 31 V 1958 r., AZASP 3/170.

${ }^{4}$ Projekt pisma okólnego Ministra Kultury i Sztuki w sprawie zasad powoływania i wynagradzania dyrektorów teatrów (oper, operetek), AZSAP 3/170.

${ }^{5}$ Dtużej zwlekać nie podobna, wstępniak, „Teatr” 1958, nr 24. 
redaktor naczelny pisma - Słuszne postulaty najbardziej kompetentnej w tej sprawie reprezentacji środowiska utonęły bez śladu w ministerstwie; wygląda na to, że po prostu odłożono je ad acta"6.

Potrzebę uchwalenia Statusu Csató uzasadniał „casusem Byrskich” w Poznaniu - gdy po jednym, bardzo udanym sezonie 1958/19597 Irena i Tadeusz Byrscy zrezygnowali z dyrekcji po konflikcie z władzami lokalnymi. Krytyk zarzucał ministerstwu opieszałość:

Centralny Zarząd Teatrów, przekształcony w Zespół dla spraw teatrów, stał się niejako adwokatem zdecentralizowanych teatrów, doradcą i obrońcą z urzędu. Jak to jednak niestety czasem się zdarza, urzędowy obrońca nie wkłada zbyt wiele serca w wykonywanie powierzonych mu obowiązków ${ }^{8}$.

Poza statusem i przedłużeniem kadencji przydałaby się też umowa regulująca wzajemne relacje Prezydiów Wojewódzkich Rad Narodowych i dyrektorów. Na ogół było bowiem tak, że Rada Narodowa składała szerokie obietnice, kandydat przyjmował hojną propozycję, a ostatecznie Rada nie spełniała żadnej zapowiedzi. Bez Statusu dyrektorzy teatrów „,uzależnieni są od kaprysów urzędników i fluktuacji personelu Rad Narodowych",

\section{Gra w ciuciubabkę}

Trudno sobie wyobrazić miny dyrektorów teatrów, gdy podczas zebrania Sekcji Teatru i Filmu Rady Kultury (20 czerwca 1960 roku) dyrektor Zespołu do spraw Teatru MKiS, Jerzy Jasieński, oświadczył, że nie są mu znane żadne projekty SPATiF w sprawie unormowania sytuacji dyrektorów teatrów. Stowarzyszenie w ciągu dwóch tygodni wystosowało dwa pisma do dyrektora Jasieńskiego, przypominając $\mathrm{mu}$ - krok po kroku - wszystkie działania od maja $1958 \mathrm{roku}^{10}$. Dyrektor Zespołu tłumaczył, że nie powiedział, iż nie jest mu znana idea czy projekt ustaleń w sprawie umów z dyrektorami, lecz wyraził się, że „nie pamięta”, czy SPATiF oficjalnie w tej sprawie wystąpił do ministerstwa. I owszem, uszła jego pamięci uchwała z 29 września 1958 roku. Przy okazji jednak wyjaśnił, iż sprawa dyrektorów

[...] nie może być na razie załatwiona, nie tylko dlatego, że nie można uzyskać zgody Ministerstwa Finansów, ale i dlatego, że sprzeciwia się załatwieniu jej ZZPIA [Związek Zawodowy Pracowników Instytucji Artystycznych], twierdząc, że sytuacja ekonomiczna dyrektorów jest częścią składową Umowy Zbiorowej i nie może być załatwiona wycinkowo, lecz tylko w ramach nowej konwencji (której nb. podpisanie przesuwa się... ad calendas Graecas!) ${ }^{11}$.

${ }^{6}$ O status dyrektora teatru, wstępniak, „Teatr” 1959, nr 21.

7 Wystawiono m.in. Wesele Wyspiańskiego ze słynną scenografią Piotra Potworowskiego.

${ }^{8}$ O status dyrektora teatru.

9 Tamże.

${ }_{10}$ Odpis pism 3459/60 z dnia 28 VI 1960 r. i 3710/60 z dnia 13 VII 1960 r. do dyrektora Zespołu ds. Teatru MKiS, AZASP 3/170.

${ }^{11}$ Pismo dyrektora Zespołu ds. Teatru do Prezydium SPATiF z dnia 19 VII 1960, AZASP 3/170. 
Sprawa Statusu ponownie została zatrzymana - na blisko dekadę. Do tematu wracali co jakiś czas członkowie Grupy Dyrektorów Teatrów SPATiF-ZASP. W roku 1962 podczas dyskusji w gronie dyrektorów Erwin Axer stwierdzał, że należałoby walczyć o usankcjonowanie uprawnień dyrektora w zakresie jego obowiązków, zadań i odpowiedzialności - na co Stanisław Witold Balicki, dyrektor Teatru Polskiego w Warszawie, odpowiadał, iż

[...] w tej chwili jest tendencja do traktowania dyrektora jak urzędnika państwowego. To się przejawia nie tylko w ustosunkowaniu się władz administracyjnych, ale również partyjnych. W związku z tym ukazał się nawet artykuł w „Trybunie Ludu” na temat mecenatu państwowego i roli dyrektora teatru, to było niemal oficjalne stanowisko władz ${ }^{12}$.

Jeszcze w styczniu 1966 roku temat wrócił na forum Grupy Dyrektorów: Zygmunt Hübner miał wątpliwości, czy należy bić się o status dyrektora, czy nie lepiej starać się o statut przedsiębiorstwa ${ }^{13}$.

Kilka miesięcy później, we wrześniu 1966 roku, MKiS i ZZPKIS [Związek Zawodowy Pracowników Kultury i Sztuki] podpisały Układ Zbiorowy pracowników teatru. Pośród wielu artykułów, poświęconych zasadom pracy w teatrze, nie było w nim żadnych, które normowałyby funkcję dyrektora teatru. Był w nim natomiast paragraf 7, który uzależniał dyrektora od rady zakładowej w kwestii kształtowania zespołu. Zapis mógł skutecznie uprzykrzyć życie każdemu dyrektorowi, szczególnie w przypadku próby zwolnienia pracownika.

W tamtych latach pozycja dyrektora teatru - nie tylko wobec rosnącego zespołu - ale przede wszystkim wobec władz lokalnych, nie była mocna. Była to niestabilna posada. Urzędnicy wydziałów kultury raz po raz rozkręcali „karuzelę stanowisk” i rozpoczynał się ogólnopolski „kontredans kilkunastu dyrektorów” - jak to zjawisko nazwał Zygmunt Greń i dodawał, że „załatwia się te sprawy przy pomocy łapanki" ${ }^{14}$. Niekiedy odwoływano dyrektora po jednym sezonie. Zdarzały się przypadki, że - bez podania przyczyn - odwoływano dyrektora w trakcie sezonu. Władze szybko traciły cierpliwość do swoich nominatów. Niekiedy też sami dyrektorzy uciekali z teatru, by objąć bardziej intratną posadę.

\section{Druga próba}

Po dekadzie ciszy w lutym 1972 roku członkowie Zarządu Głównego SPATiF-ZASP dowiedzieli się, że Związek Zawodowy Pracowników Kultury i Sztuki opracowuje projekt Statusu dyrektora instytucji artystycznej. Projekt Związku zawodowego

12 Protokół z posiedzenia Grupy Dyrektorów Teatrów ZASP w dnia 8 I 1962 r., teczka Protokoty z narad dyrektorów teatrów 1958-1963, AZASP, syg. 3/124.

13 Protokół z zebrania Prezydium Grupy Dyrektorów z dnia 17 I 1966 r., teczka Protokoły z Zebrań Grupy Kierowników Teatrów 1964-1965, AZASP syg. 3/125.

${ }^{14}$ Zygmunt Greń, Dyrektorzy teatru i... ogon komety [w:] tenże, Taki nam się snuje dramat... Szkice z teatru 1971-1976, Kraków 1978, s. 314. 
wywołał opór - przede wszystkim został opracowany bez konsultacji ze SPATiF dlatego też Zarząd postanowił opracować własną koncepcję statusu dyrektora ${ }^{15}$.

Już miesiąc później Zarząd dysponował kontrpropozycją. Prezes SPATiF, Gustaw Holoubek stwierdzał, że

[...] w chwili obecnej trzeba powiedzieć, że postulat dotyczący naszego (tj. SPATiF-u) udziału w nominowaniu kierownictw artystycznych teatrów został przyjęty przez władze polityczne z zadowoleniem. Odpowiednie komórki administracji zostały zobowiązane do powiadomienia o tym władz terenowych ${ }^{16}$.

W propozycji Statusu dyrektora normowano w ten sposób obowiązki i prawa dyrektora, a przede wszystkim powoływania i odwoływania dyrektora (powołanie na co najmniej trzyletnią kadencję, odwołanie - z pięciomiesięcznym wyprzedzeniem).

Przez cały rok 1972 na posiedzeniach Zarządu SPATiF-ZASP omawiano projekt statusu dyrektora. W 1973 roku został przedstawiony w ministerstwie. Projekt spotkał się z tak dobrym przyjęciem, iż został włączony jako załącznik do Postulatów Departamentu Teatru, Muzyki i Estrady dotyczacych nowej struktury organizacyjnej i zasad wynagradzania w teatrach dramatycznych i lalkowych (jako Status dyrektora instytucji artystycznej), podstawowych resortowych wytycznych dotyczących opracowywanej reformy życia teatralnego. Wydawało się więc, że status będzie zatwierdzony jeszcze przed zawarciem nowego Układu Zbiorowego.

Pierwszym elementem reformy miała być ,regulacja płac”, czyli podwyżka uposażeń w teatrze. W roku 1974 władze SPATiF, analizując projekt uchwały Rady Ministrów w tej sprawie uznały, że Status dyrektora ,jest dokumentem, bez którego nie może wejść w życie reforma płac, wprowadzenie statusu musi być równoległe, z uwagi na olbrzymie uprawnienia dyrektora wynikające z zarządzenia o reformie płac" ${ }^{\prime 17}$. Ostatecznie regulacja została przeprowadzona w sierpniu 1974 roku bez żadnych dodatkowych dokumentów.

Początkowo przyjmowano to jako poślizg. W styczniu 1975 roku prezes Holoubek, podsumowując regulację płac, mówił o Statusie dyrektora jak o rzeczy dokonanej, widział w nim jedną z zalet tej reformy.

W konsekwencji czego (nie wszyscy zapewne zdają sobie z tego sprawę) teatry będą miały możność tworzenia swojej własnej polityki artystycznej w sposób daleko bardziej swobodny i odpowiedzialny niż to miało miejsce dotychczas.

W lutym 1975 roku dyrektor Departamentu Teatru, Bogumił Pałasz, przesyłał projekt Statusu Dyrektora Teatru z uwagą, że będzie „mam nadzieję ostatnią” propozycją brzmienia dokumentu ${ }^{18}$.

15 Protokół nr 13 z zebrania Zarządu Głównego SPATiF - ZASP z dnia 7 II 1972 r., s. 2-3, Teczka Protokoły Prezydium ZG ZASP 1971-1972, AZASP 3/75.

${ }^{16}$ Protokół nr 14 z zebrania Prezydium Zarządu Głównego Stowarzyszenia Polskich Artystów Teatru i Filmu w dniu 13 III 1972 r., s. 1-2, Teczka Protokoty Prezydium ZG ZASP 1971-1972, AZASP 3/75.

${ }_{17}$ Wyciąg z protokołu posiedzenia Prezydium ZG SPATiF z 10 VI 1974, AZASP syg. 9/154.

18 Odpis pisma Bogumiła Pałasza, dyrektora DTMiE z dnia 6 II 1975 r. do prezesa SPATiF, Gustawa Holoubka, teczka Status Dyrektora Teatru, kierownika literackiego i reżysera 1975-1976, AZASP 3/44. 
Niestety. Dalsze prace trwały jeszcze przez blisko dwa lata (1975-1976). Prócz Statusu dyrektora opracowano także projekty statusu reżysera i kierownika literackiego (próbka stylu: „Zawód reżysera jest zawodem twórczym. Reżyserem jest osoba posiadająca pełne kwalifikacje twórcze").

W roku 1976 nad Statusem dyrektora wciąż debatował Zarząd Główny SPATiF, zapraszając na naradę wybranych szefów scen. Dyrektor Starego Teatru, Jan Paweł Gawlik, niebezpodstawnie obawiał się, że „przy istniejącej decentralizacji będzie bardzo trudno wywalczyć wprowadzenie w życie wszystkich zasad Statusu"19. Zwracano też uwagę na niebezpieczeństwo ustalania sztywnych kryteriów kwalifikacyjnych dla kandydatów na dyrektorów teatrów. Na jesieni 1976 roku trwały konsultacje Statusu w kołach i oddziałach ZASP. Jeszcze w marcu 1977 roku swoje uwagi nadesłał wiceprzewodniczący ZZPKiS, Andrzej Gordon.

Wreszcie kształt dokument zatwierdzono - powstał nieduży objętościowo, niespełna czterostronicowy dokument. Status regulował, kto może być dyrektorem teatru (tylko pracownik artystyczny), kto powołuje dyrektora (władze lokalne w porozumieniu z MKiS, po zasięgnięciu opinii SPATiF-ZASP), okres dyrekcji (nie krótszy niż trzy lata), tryb powołania i odwoływania (na pół roku przed rozpoczęciem/zakończeniem kadencji). Określono też najogólniej prawa i obowiązki dyrektora. Ważnym prawem była możliwość ustalania stawek umów-zleceń i umów o dzieło ${ }^{20}$.

\section{Status dyrektora w praktyce}

Pozostało czekać na owoce Statusu. Inaugurując ogólnopolską naradę dyrektorów i kierowników artystycznych teatrów dramatycznych (23 maja 1977 roku) wiceminister kultury i sztuki Aleksander Syczewski oświadczył:

Wychodząc z założenia, że sprawy te nie mogą opierać się tylko na ogólnie obowiązujących przepisach czy dobrej woli dyrektorów instytucji artystycznych, uznaliśmy za niezbędne ujęcie praw i obowiązków dyrektorów teatrów, dyrektorów instytucji artystycznej w formie zwartego dokumentu - statusu dyrektora teatru. Dokument ten został ostatecznie sprecyzowany po licznych dyskusjach i konsultacjach, przy aktywniej współpracy i zaangażowaniu Zarządu Głównego SPATiF-u, SPAM-u i Związku Zawodowego [...]. Określiliśmy tam wymagania, jakie będą stawiane kandydatom na dyrektora teatru i dyrektora artystycznego, tryb, okres termin powoływania i zwalniania dyrektora, obligatoryjną zasadę konsultowania ze SPATiF-em kandydatów. Chcemy wdrażać obowiązek przedkładania założeń programowo-artystycznych, organizacyjnych i kadrowych przez kandydata na dyrektora, a następnie obowiązek rozliczania w zespole minionego sezonu, obowiązek właściwego wykorzystania zespołu artystycznego, troskę o rozwój artystyczny jego poszczególnych członków. Dokument określa zasady współdziałania z POP, radą zakładową, kołem SPATiF-u, słowem zasady funkcjonowania

19 Narada przedstawicieli Prezydium ZG SPATiF z zaproszonymi dyrektorami niektórych teatrów - w dniu 17 V 1976 r., s. 2, teczka Status Dyrektora Teatru, kierownika literackiego i reżysera 1975-1976, AZASP 3/44.

${ }^{20}$ Status dyrektora teatru, 1977, AJS - PDT IT. 
teatru jako twórczego zespołu w ogólnie obowiązujących strukturalnych normach socjalistycznej instytucji ${ }^{21}$.

Minister zapowiedział wówczas, że „w najbliższych dniach” pismo przewodnie ministra wraz ze Statusem dyrektora teatru otrzymają władze wojewódzkie, szefowie instytucji, ogniwa stowarzyszeń i związków. Pewnie tak się stało. W archiwum ZASP znajduje się ta ostateczna wersja Statusu rozsyłana do teatrów w 1977 roku. Zwraca uwagę pewien drobny zabieg redakcyjny. Status dyrektora opatrzono nadtytułem - Wytyczne w sprawie statusu dyrektora teatru. Nie nadano zatem Statusowi charakteru zarządzenia ani innej skutecznej formuły prawnej. Był tylko zaleceniem. Dwadzieścia lat przygotowań nie doprowadziło do stworzenia faktycznych przepisów regulujących sposób funkcjonowania dyrektorów teatrów.

Jak Status działał w praktyce, widać choćby w korespondencji między prezesem Holoubkiem a wiceministrem Lorancem ${ }^{22}$. W listopadzie 1979 roku SPATiF zwrócił się do resortu kultury w sprawie nierespektowania zasad Statusu przy powoływaniu dyrektorów kilku teatrów. MKiS thumaczyło rozmaicie: a to opinia SPATiF została nadesłana ze zbyt dużym opóźnieniem (Opera Wrocławska), a to pilność sprawy powodowała, że powołano dyrektora bez konsultacji (Teatr im. Siemaszkowej w Rzeszowie), a to władze postąpiły zgodnie z opinią zespołu tego teatru (Teatr Rozmaitości w Krakowie). W swej odpowiedzi Władysław Loranc zapewniał, że w sierpniu 1979 roku ,podjęliśmy kroki do uregulowania trybu konsultacji i że będziemy w dalszym ciągu dążyć do pełnej realizacji postanowień Statusu Dyrektora”. Natomiast dla uniknięcia dalszych ,nieporozumień w praktycznym działaniu” MKiS oraz Ministerstwo Administracji, Gospodarki Terenowej i Ochrony Środowiska miały przygotować wspólny list do wojewodów w tej sprawie i dokładnie omówić ją na naradzie $\mathrm{z}$ wicewojewodami. Jeśli nawet zrealizowano ten zamiar, to raczej nie mogło to spowodować jakichś formalnych skutków.

\section{Reformy w cieniu junty}

Wiosną 1981 roku redaktor naczelny „Teatru” Jerzy Sokołowski podsumowywał funkcjonowanie Statusu dyrektora. Jako długoletni wicedyrektor Departamentu Teatru MKiS był on w tej kwestii nieźle zorientowany. Jego zdaniem, dokument prawidłowo formułował prawa i obowiązki dyrektora, mógł ułatwić organizację pracy artystycznej, lecz niestety nie nadano mu odpowiedniej rangi prawnej.

Przesądziło to niejako z góry brak możliwości pełnego jego wyegzekwowania zarówno przez władze, przedstawicielstwo środowiska, jak i dyrektorów teatrów. U swego „startu” został więc skazany na dobrą jedynie wolę adresatów ${ }^{23}$.

21 A. Syczewski, Dziś i jutro polskiego teatru, „Życie Literackie” 1977, nr 22.

${ }^{22}$ List podsekretarza stanu w Ministerstwie Kultury i Sztuki z dnia 7 I 1980 r., 1.dz. V BOZ/58/79 do Gustawa Holoubka, prezesa Zarządu Głównego SPATiF, teczka Mianowania na stanowiska dyrektorów i kierowników artystycznych. Korespondencja 1980-1981, AZASP 3/177.

${ }_{23}$ J. Sokołowski, Jedna sprawa, ,Teatr” 1981, nr 6. 
Obserwując w karnawale „Solidarności” liczne teatralne przesilenia, Sokołowski stwierdzał, że status

[...] nie był w stanie niczego zmienić w budzącej powszechne zastrzeżenia strukturze organizacyjnej, kadrowej i artystycznej naszego teatru, która doprowadziła do stanu, jakiego dość żałosne efekty dziś obserwujemy.

W tamtym bowiem czasie dla władz najbardziej niepokojąca była gwałtowna fala zmian na stanowiskach dyrektorów teatrów. Wiele zespołów - silnych ,Solidarnością" - wypowiedziało posłuszeństwo dotychczasowym dyrektorom. W ciągu sezonu 1980/1981 zrezygnowało ze swoich stanowisk dwudziestu pięciu dyrektorów teatrów dramatycznych. Na początku kolejnego sezonu dokonało się blisko dziesięć zmian. „Sztandar Młodych” wołał: „Dyrektor potrzebny do bicia” i pisał o antydyrektorskim przewrocie.

Warto wymienić nazwiska odchodzących dyrektorów, by uświadomić sobie skalę zmian. W Krakowie: Krystyna Skuszanka odeszła z Teatru im. Słowackiego, Jan Paweł Gawlik ze Starego; w Warszawie: Mariusz Dmochowski z Nowego, Tadeusz Łomnicki z Na Woli; Maciej Prus z Wybrzeża w Gdańsku, Jerzy Grzegorzewski z Polskiego we Wrocławiu, Roman Kordziński z Polskiego w Poznaniu, Roman Kłosowski z Powszechnego w Łodzi, Michał Pawlicki ze Śląskiego w Katowicach, Jan Skotnicki z Płocka, Jacek Gruca z Elbląga, Andrzej Rozhin z Koszalina, Andrzej Maria Marczewski z Wałbrzycha. Jedyny w swoim rodzaju był przypadek w stołecznego Teatru Współczesnego, gdzie nastąpiła planowa sukcesja - Erwina Axera zastąpił Maciej Englert. Rzecz niespotykana w Polsce nawet w spokojniejszych czasach.

W lutym 1981 roku Józef Tejchma, który po raz drugi został ministrem kultury i sztuki, zaprosił do współpracy na stanowisku dyrektora Departamentu Teatru, Henryka Bieniewskiego, który w latach 1965-1968 był już dyrektorem resortowego Zespołu ds. Teatru. Minister zlecił dyrektorowi opracowanie reformy życia teatralnego i dobrania odpowiedniego składu zespołu konsultacyjnego ${ }^{24}$, który taką propozycję stworzy. W pracach nad projektem brali udział m.in.: Izabella Cywińska, Kazimierz Dejmek, Zygmunt Hübner, Andrzej Jarecki, Jerzy Krasowski, Mieczysław Marszycki, Jerzy Zegalski; Jan Englert, Andrzej Szczepkowski, Jerzy Stuhr, Halina Winiarska, Andrzej Zaorski, Andrzej Ziębiński.

W projekcie zaproponowano stworzenie trzech głównych modeli instytucji teatralnej, a mianowicie: tradycyjnego (zespół, budynek), impresaryjnego (bez zespołu, budynek, własne produkcje) i ośrodka teatralnego (bez zespołu, budynek, tylko występy gościnne). Według założeń projektu zespoły miały się skupiać wokół indywidualności twórczej. Mandat do działalności twórca otrzymywać miał od mecenasa bądź grupa miała wysuwać spośród siebie lidera, który pozyska mecenat finansowy i opiekę. Kierownik podpisywałby z mecenasem umowę na trzy lub cztery lata, w której sprecyzowane zostałyby warunki organizacyjne i finansowe oraz zasady

${ }^{24}$ M. Rosenberg, Działalność sekcji branżowych NSZZ „, Solidarnośc” w latach 1980-1981 na przyktadzie Krajowej Komisji Porozumiewawczej NSZZ ,, Solidarność” Pracowników Teatru, „Polska 1944/45-1989” 2016, nr 14, s. 219 i 221. 
nadzoru merytorycznego. Umowa musiałaby zawierać również odpowiednie gwarancje dla zespołu, a przebieg jej realizacji z obu stron miał być przedmiotem okresowej społecznej oceny. Aby zrealizować te pomysły, zakładano śmiało grupowe zwolnienia w zespołach teatralnych. Aktorzy bezetatowi mieli znaleźć się pod opieką Regionalnych Agencji Artystycznych ${ }^{25}$. Był to projekt idealny i maksymalistyczny.

Gdy w stanie wojennym, w czerwcu 1982 roku, Henryk Bieniewski przedstawiał szefostwu MKiS projekt nowego modelu życia teatralnego, to propozycje dotyczące dyrektora i zespołu artystycznego już nie szły tak daleko. Już nie było mowy o zwolnieniach. Zachowano pięknie brzmiące uwagi o czołowej roli kierownika artystycznego - to wokół niego i jego programu skupiać się miał zespół. Jednak w kolejnym zdaniu pojawiała się informacja, która zaprzeczała poprzedniemu, a mianowicie: „Kierownika artystycznego (dyrektora) powołuje i odwołuje organ założycielski w porozumieniu z zespołem"26. To zatem dyrektor kształtuje zespół, ale najpierw zespół decyduje, kto będzie dyrektorem.

Przewidywano jednak dookreślenie pozycji dyrektora - miał podpisywać kilkuletnią umowę z organem założycielskim, precyzującą prawa i obowiązki obu stron, warunki organizacyjne oraz szczegóły nadzoru merytorycznego ze strony mecenasa. Umowa ta miała zawierać również odpowiednie gwarancje dla zespołu, a przebieg realizacji umowy z obu stron powinien być przedmiotem okresowej społecznej oceny.

MKiS zdecydowało jednak, że zanim zostanie wdrożona reforma teatru, najpierw będzie przygotowana ustawa o instytucjach artystycznych, która uporządkuje sprawy dotychczasowych przedsiębiorstw widowiskowych i przystosuje je do realiów pierwszego etapu reformy gospodarczej, która próbowała przestawić przedsiębiorstwa państwowe (więc i teatry) na zasady bardziej rynkowe.

\section{Ustawowe umocowanie}

Dwa lata zajęło przygotowania ustawy, którą uchwalono w grudniu 1984 roku $^{27}$. Instytucjami artystycznymi w rozumieniu ustawodawcy były m.in. teatry, opery, operetki, chóry i orkiestry. Ustawa przekształciła przedsiębiorstwa państwowe użyteczności publicznej w instytucje artystyczne, które uznano za ,jednostki wyodrębnione pod względem prawnym, organizacyjnym i ekonomiczno-finansowym". W tym sensie ustawa była spełnieniem postulatów powtarzanych od lat pięćdziesiątych XX wieku.

$\mathrm{W}$ dwóch artykułach $(10,11)$ ustawa regulowała też kwestie dyrektora naczelnego instytucji, który mógł także pełnić funkcję dyrektora artystycznego. Dyrektor naczelny miał prawo samodzielnie podejmować decyzje, organizował działalność instytucji artystycznej oraz odpowiadał za

${ }^{25}$ Projekt opisuję za: L. Cehl, Myśmy wszystko zapomnieli, „Scena” 2001, nr 3.

${ }^{26}$ Zarys nowego modelu życia teatralnego. Projekt, 1982, Archiwum MKiDN, syg. 1243/17.

${ }^{27}$ Ustawa z dnia 28 grudnia 1984 r. o instytucjach artystycznych, Dz.U. 1984 nr 60 poz. 304. 
[...] całokształt jej działalności, w szczególności: reprezentuje instytucję na zewnątrz oraz odpowiada za: działalność ideowo-artystyczną i repertuarową; dobór i właściwe wykorzystanie kadr [...]; zapewnienie członkom zespołu warunków rozwoju artystycznego; zapewnienie pracownikom właściwych warunków pracy i socjalno-bytowych; właściwą gospodarkę mieniem i środkami finansowymi.

Ustawa przewidywała, że mogą być powołani oddzielnie dyrektor naczelny i dyrektor artystyczny, więc precyzowano, że do zadań tego drugiego należy kształtowanie programu ideowo-artystycznego, repertuaru, dobór kadr artystycznych i właściwe ich wykorzystanie.

Dyrektora naczelnego powoływał i odwoływał organ założycielski po zasięgnięciu opinii Ministra Kultury i Sztuki oraz właściwego stowarzyszenia twórców/artystów. W przypadku instytucji podlegających bezpośrednio ministrowi wystarczyła tylko opinia stowarzyszenia. Dyrektora artystycznego powoływał i odwoływał organ założycielski na wniosek dyrektora naczelnego.

Nadzór organu założycielskiego nad instytucją sprowadzał się w swej podstawowej wersji do okresowych kontroli i ocen działalności (m.in. oceniano zgodność z celami polityki kulturalnej państwa, działalność artystyczną, stopień zaspokajania potrzeb kulturalnych społeczeństwa, poziom artystyczny czy wyniki ekonomiczne). Wprowadzono do struktury instytucji rady artystyczno-programowe, które, powoływane przez dyrektora, stanowić miały organ doradczy i opiniodawczy oraz „czynnik społeczny" w zarządzaniu teatrem. W praktyce znaczenie rady było czysto umowne.

Ta ważna ustawa niepokoiła jednak środowiska twórcze i prawnicze. Obawę budziły zapisy dotyczące uprawnień MKiS związanych z prowadzeniem rejestru instytucji artystycznych ${ }^{28}$. Resort mógł odmówić wpisania nowo powołanej instytucji, jeśli jej „zamierzona działalność” byłaby sprzeczna z celami i zadaniami instytucji artystycznych. Resort mógł również wykreślić z rejestru działającą instytucję, jeżeli „prowadzona przez nią działalność jest sprzeczna z zapisami ustawy, ze statutem lub w inny sposób narusza obowiązujący porządek prawny” (art. 9 ust. 2). W PRL-u rządzonym przez gen. Jaruzelskiego takie zapisy stanowiły straszak na niepokornych, niemniej jednak to ten akt prawny niespełna pięć lat później zablokował plany prywatyzacji teatrów. Przez porównanie z innymi obszarami kultury, które w momencie transformacji ustrojowej funkcjonowały jako przedsiębiorstwa (np. wydawnictwa książkowe i muzyczne), można sobie wyobrazić, jaki los czekałby podatne na ewentualne „przekształcenia własnościowe” teatry-przedsiębiorstwa państwowe.

\section{Nowy ustrój kultury}

Zmiany ustrojowe roku 1989 miały też przynieść nowy kształt życia kulturalnego. Ministerstwo Kultury i Sztuki pod kierownictwem Izabelli Cywińskiej bardzo szybko zaczęło prace nad ustawą o działalności kulturalnej. Powstawały kolejne

${ }^{28}$ S. Biernat, Położenie prawne instytucji artystycznych, „Państwo i Prawo” 1985, nr 7-8, s. 59. 
wersje. W końcu w październiku 1991 roku w ostatnich dniach prac sejmu kontraktowego przyjęto Ustawę o organizowaniu i prowadzeniu działalności kulturalnej29. Wprowadziła ona pojęcie instytucji kultury, obejmującej dłuższą listę rodzajów instytucji - już nie tylko artystycznych, lecz także upowszechnieniowych (biblioteki, muzea, galerie).

W pierwotnym tekście ustawy kwestie dyrektorów regulowały trzy krótkie artykuły. W art. 15 określono tryb powoływania dyrektora narodowej lub państwowej instytucji kultury - powoływać go mógł organizator na czas określony lub nieokreślony po zasięgnięciu opinii właściwych stowarzyszeń twórczych. Odwołanie następowało w tym samym trybie. Doprecyzowywano, że dyrektora powołanego na czas określony można odwołać przed upływem tego okresu jedynie na własną prośbę lub „W szczególnie ważnych i uzasadnionych przypadkach dotyczących funkcjonowania instytucji kultury”. W art. 16 stwierdzano, że powołanie dyrektora może nastąpić w wyniku konkursu na podstawie ramowego regulaminu określonego przez MKiS.

Zadania dyrektora sformułowano krótko: ,zarządza instytucją i reprezentuje ją na zewnątrz" (art. 17), co dało dyrektorowi uprawnienia do samodzielnego zarządzania, od nieskrępowanego kreowania linii repertuarowej, tworzenia struktury organizacyjnej, swobodnego zarządzania personelem i finansami, aż do ustalania cen biletów $\mathrm{i}$ innych usług. Jeśli coś dyrektora mogło ograniczać, to wysokość dotacji. W połowie lat dziewięćdziesiątych XX wieku Andrzej Lis zauważał zasadniczą zmianę:

[...] w coraz większym stopniu zaangażowani są w sprawy organizacyjnie, finansowe, a bardzo często także i personalno-związkowe zespołów, [...] pochłaniają im te zajęcia więcej czasu niż w przeszłości, i czynności te nie pozwalają dyrektorom-kierownikom teatrów na reżyserowanie przedstawień ${ }^{30}$.

Z czasem sytuacja teatrów się ustabilizowała i dyrektorzy reżyserzy bardziej harmonijnie łączą administrowanie z pracą artystyczną.

Pierwsza poważna nowelizacja nastąpiła już po pięciu latach ${ }^{31}$. Zmieniono wówczas brzmienie artykułu 15. Poszerzono grono ciał opiniujących kandydata, zamiast stowarzyszeń twórców - wprowadzono związki zawodowe działające w instytucji oraz stowarzyszenia zawodowe i twórcze. W przypadku państwowych instytucji kultury (dla których organizatorem był wojewoda) powołanie i odwołanie dyrektora wymagało zgody ministra. W przypadku dyrektorów instytucji samorządowych wymagane było zasięgnięcie opinii ministra. Co więcej, zdecydowano, że wymóg opinii nie jest obligatoryjny dla wszystkich, ale dotyczy tylko instytucji, które znajdą się na liście określonej zarządzeniem ministra. Wraz z postępem procesu decentralizacji lista będzie się wydłużać: w 1996 roku były na niej 44 teatry (5 muzycznych,

${ }^{29}$ Ustawa z dnia 25 października 1991 r. o organizowaniu i prowadzeniu działalności kulturalnej, Dz.U. 1991 nr 114 poz. 493.

${ }^{30}$ A. Lis, Teatry dramatyczne w czasie przemian w latach 1989-1997 [w:] T. Kostyrko (red.), Kultura Polska 1989-1997. Raport, Warszawa 1997, s. 62.

${ }^{31}$ Ustawa z dnia 27 czerwca 1996 r. o zmianie ustawy o organizowaniu i prowadzeniu działalności kulturalnej, Dz.U. 1996 nr 90 poz. 407. 
24 dramatyczne, 15 lalkowych) ${ }^{32}$ - w 1999 już 110 (17 muzycznych, 67 dramatycznych, 26 lalkowych ${ }^{33}$.

W nowelizacji dookreślono też warunki wstępne współpracy dyrektora z władzami:

Organizator przedstawia kandydatowi na stanowisko dyrektora warunki organizacyjno-finansowe działalności instytucji kultury. Kandydat przedstawia organizatorowi program działania instytucji kultury.

Znacznie poszerzono też listę przypadków, w których

[...] dyrektor instytucji kultury, powołany na czas określony, może być odwołany przed upływem tego okresu: 1) na własną prośbę, 2) z powodu choroby trwale uniemożliwiającej wykonywanie obowiązków, 3) z powodu naruszenia przepisów prawa w związku z zajmowanym stanowiskiem, 4) w razie odstąpienia od realizacji uzgodnionego z organizatorem programu działania instytucji kultury, 5) w razie przekazania państwowej instytucji kultury [przekazanie samorządowi].

W odróżnieniu zatem od PRL kwestią nie było już, czy regulować funkcjonowanie dyrektorów, ale jak regulować. Dlatego też w ostatniej części artykułu skupiam się na losach ustawy o organizowaniu i prowadzeniu działalności kulturalnej. W ciągu ponad dwóch dekad ustawa była więcej niż dwadzieścia razy nowelizowana. Stopniowo dostosowywano ustawę do reformy samorządowej. „Artykuły dyrektorskie” zaś nowelizowano pięć razy. Znajdzie to odbicie w rosnącej objętości tych trzech artykułów, które według tekstu jednolitego z 2017 roku zajmują już cztery strony. Inicjatywa zmiany zapisów wychodziła zarówno od władz, jak i od dyrektorów.

\section{Dyrektor, czyli menedżer}

Dyrektorzy od początku przemian postulowali, by obok formuły prawnej ,powołania" na stanowisko, wprowadzić także możliwość kontraktu menedżerskiego. W 1990 roku Maciej Englert w trakcie prac nad ustawą zwracał uwagę na potrzebę wprowadzenia takiego rozwiązania:

Postulujemy od lat system zawierania kontraktów z dyrektorem. Ustawa kolejny raz proponuje powoływanie o odwoływanie. Znowu program artystyczny teatru, jego statut, jego finansowanie jest sprawą niezależną od powołania lub odwołania dyrektora. [...] Kontrakt z dyrektorem powinien zawierać nie tylko terminy sprawowania przez niego dyrekcji, ale właśnie cele

32 Zarządzenie Ministra Kultury i Sztuki z dnia 10 grudnia 1996 r. w sprawie ustalenia listy komunalnych instytucji kultury, w których powołanie i odwołanie dyrektora wymaga zasięgnięcia opinii Ministra Kultury i Sztuki, M.P. 1997 nr 3 poz. 15.

${ }^{33}$ Rozporządzenie Ministra Kultury i Sztuki z dnia 29 grudnia 1998 r. w sprawie ustalenia listy samorządowych instytucji kultury, w których powołanie i odwołanie dyrektora wymaga zasięgnięcia opinii ministra właściwego do spraw kultury, Dz.U. 1998 nr 166 poz. 1218. 
programowe, wysokość przyznanych środków i wszystko to, co mieści się w statucie, i ten właśnie kontrakt powinien być parafowany przez ZASP ${ }^{34}$.

Już na przełomie roku 1992/1993 warszawski samorząd próbował wprowadzić kontrakty: umowy o pracę z dyrektorami teatrów zostały uzupełnione - decyzją Zarządu Związku Dzielnic-Gmin Warszawy - o kontrakty gwarantujące dyrektorom prowadzenie teatru przez cały okres jego obowiązywania, a także określające poziom minimalnej dotacji miasta. Teatry zobowiązały się w nich do przygotowania określonej liczby premier i do zaprezentowania określonej liczby przedstawień w roku kalendarzowym. Do zawierania kontraktów dyrektorzy nie byli zmuszani; spośród dwunastu teatrów podpisało je siedmiu dyrektorów tych instytucji. Miasto gwarantowało dotację na poziomie co najmniej 70\% kosztów działalności, teatry planowały od 2 do 5 premier i 150 spektakli w ciągu roku.

W praktyce kontrakty w Warszawie nie zadziałały. Dyrektorzy ograniczali zaplanowaną liczbę premier z powodu braku środków finansowych. Urzędnicy rzecz ze zrozumieniem akceptowali:

Należy w tym miejscu samokrytycznie przyznać, że na [słabe] wywiązywanie się przez teatry z obowiązków przyjętych kontraktami mogło również mieć wpływ niewywiązywanie się miasta z przyjętych obowiązków, zwłaszcza w zakresie terminowości przekazywania dotacji w wysokości określonej kontraktem ${ }^{35}$.

Do tego dochodziły podwyżki cen (np. za ogrzewanie, czynsz), co dodatkowo uszczuplało pulę środków m.in. na kolejne premiery. Okazało się, że kontrakt bywa bardziej kłopotliwy dla organizatora niż dyrektora.

Mimo tych doświadczeń dyrektorzy popierali wprowadzenie kontaktów menedżerskich, które w zamierzeniu dawałyby szansę na stabilną pracę teatrów. Był to jeden z postulatów powołanego w roku 1993 Stowarzyszenia Dyrektorów Teatrów. Na fali reformy samorządowej udało się doprowadzić do wprowadzenia punktu 4a w art. 15 Ustawy o organizowaniu i prowadzeniu działalności kulturalnej. Przewidziano, że

[...] organizator może powierzyć zarządzanie instytucją kultury osobie fizycznej lub prawnej [...] na podstawie umowy o zarządzaniu instytucją kultury zawartej między organizatorem a zarządcą na czas oznaczony, nie krótszy niż trzy lata (kontrakt menedżerski) ${ }^{36}$.

Taką umowę należało przygotować zgodnie z ustawą o przedsiębiorstwach państwowych - a powinna ona określać obowiązki dyrektora w zakresie bieżącego zarządzania oraz zmian i usprawnień podległej mu instytucji/przedsiębiorstwa, zasady wynagradzania dyrektora, kryteria oceny efektywności zarządzania, a także odpowiedzialność za powierzoną instytucję.

${ }^{34}$ M. Englert, Uwagi do projektu ustawy o działalności kulturalnej, s. 2, PDT - AJS.

${ }_{35}$ Raport. Informacja o stanie teatrów miejskich, oprac. Wydział Kultury i Sztuki Biura Zarządu m. st. Warszawy, marzec 1995, s. 8.

${ }^{36}$ Ustawa z dnia 24 lipca 1998 r. o zmianie niektórych ustaw określających kompetencje organów administracji publicznej - w związku z reformą ustrojową państwa, Dz.U. 1998 nr 106 poz. 668. 
Życie pokazało, że samorządowcy nie skorzystali z kontraktu menedżerskiego. W 2002 roku Warcisław Kunc, ówczesny dyrektor szczecińskiej Opery na Zamku, publicznie dzielił się wątpliwością: „nie wiem, czy ktokolwiek dziś w Polsce zarządza teatrem na podstawie takiej umowy" ${ }^{37}$.

Ryszard Markow wskazywał powód takiego stanu rzeczy, opisując różnice w sposobie zatrudnienia dyrektora. Powołanie to umowa o pracę, umowa starannego działania -

[...] zobowiązujemy się na jej podstawie zarządzać instytucją w granicach prawa, najlepiej jak potrafimy w warunkach, na które wpływ mamy znacznie ograniczony. Nasz chlebodawca nie stawia przed nami żadnych konkretnych zadań. Instytucja ma funkcjonować. Jakoś funkcjonować ${ }^{38}$.

\section{Z kolei kontrakt to}

[...] umowa cywilnoprawna, niemal umowa o dzieło. Tu staranne działanie nie wystarczy. Tu trzeba być skutecznym. Właściciel wyznacza cele, ustala misję, określa precyzyjnie zadanie, wyznacza termin i zobowiązuje się do współpracy. [...] Z menedżerem trzeba ustalić, co ma być. Opera czy kabaret, teatr stały, zespołowy czy impresariat. [...] I trzeba wiedzieć, jakie skutki kulturowe, społeczne, gospodarcze, ekonomiczne i polityczne zrodzi ta decyzja. I jeśli jest to decyzja przemyślana, a nie przypadkowa, trzeba wspierać menedżera skutecznie i do bólu, by mógł tę misję wypełnić. Trzeba się wywiązać z kontraktu. Wzajemnie ${ }^{39}$.

Ten doświadczony dyrektor teatrów w różnych miastach uważał też, że niewiele jest w Polsce samorządów dysponujących urzędniczym potencjałem intelektualnym i chęcią do takiej współpracy.

Ale to nie tylko tak. Samorządy nie podpisywały takich umów, ponieważ nie chciały podejmować długofalowych zobowiązań finansowych. Ponadto przepisy dotyczące powierzenia w zarząd okazały się zbyt zawiłe. W roku 2008 warszawski ratusz próbował na podstawie ustawy powierzyć zarządzanie Teatrem Ochoty osobie prawnej - stowarzyszeniu. Po długich konsultacjach z prawnikami skończyło się „zwykłym” powołaniem.

\section{Konkursy i kadencje}

Konkursy na dyrektorów, zgodnie z ustawą, organizowano od początku lat dziewięćdziesiątych XX wieku. Ich powodzenie zależało jednak wyłącznie od dobrej woli organizatora, bo choć sposób ich przeprowadzenia był regulowany ${ }^{40}$, to jednak

37 W. Kunc, Organizacja i zarzadzanie teatrem w Polsce na przyktadzie Opery na Zamku [w:] Międzynarodowa Konferencja ,, Teatry w Europie”. Organizacja, finansowanie i wspótpraca transgraniczna, Szczecin 2003, s. 48.

${ }^{38}$ R. Markow, Po co dyrektorowi teatru kontrakt menadżerski? [w:] II Międzynarodowa Konferencja ,, Teatry w Europie”. Teatr-otoczenie spoteczne, prawne i finansowe, Szczecin 2004, s. 148.

39 Tamże, s. 150.

40 Zarządzenie Ministra Kultury i Sztuki z dnia 2 marca 1992 r. w sprawie ramowego regulaminu konkursu na dyrektora instytucji kultury, M.P. $1992 \mathrm{nr} 10$ poz. 70. 
ani wyniki konkursu, ani opinie stosownych komisji nie były obligatoryjne dla władz ${ }^{41}$. Także opinia ministra w kwestii powołania i odwołania dyrektora samorządowych instytucji kultury nie miała praktycznego znaczenia. Władze samorządowe mogły zrobić, co chciały.

Tak stało się w 2003 roku w głośnym przypadku powołania Grzegorza Królikiewicza na stanowisko dyrektora artystycznego Teatru Nowego w Łodzi. Prezydent miasta, Jerzy Kropiwnicki, zdecydował się na tę nominację wbrew zespołowi, opinii ZASP, wbrew sprzeciwowi całej teatralnej Polski, a nawet wbrew opinii ministra. Po wycieńczającym proteście zespół teatru chciał niejako w ostatniej instancji odwołać się do autorytetu ministra, którym był wówczas Waldemar Dąbrowski. Ze zdziwieniem wszyscy zainteresowani odkryli, ze ministerstwo - mimo wydania negatywnej opinii - nie ma żadnej możliwości wpłynięcia na decyzję samorządu.

Ta bolesna niemoc Ministerstwa Kultury spowodowała kolejną nowelizację ustawy, która wprowadziła szczegółowe rozwiązania dotyczące konkursu na dyrektora instytucji kultury ${ }^{42}$. Artykuł 16 niezmiennie stwierdza, że „kandydata na stanowisko dyrektora instytucji kultury można wyłonić w drodze konkursu”, jednak - to novum - w „samorządowych instytucjach kultury, których wykaz określi w drodze rozporządzenia minister", wyłonienie kandydata na stanowisko dyrektora następuje w drodze konkursu. Minister daje tym samorządom możliwość powołania dyrektora bez przeprowadzenia konkursu, ale tylko za swoją zgodą. Dodać też należy, że minister umieszcza instytucje na liście, ,biorąc pod uwagę ich znaczenie dla kultury narodowej". To sformułowanie decyduje, że w obowiązujących wykazach nie ma publicznych teatrów rozrywkowych. Ten zapis dał ministrowi kultury największy wpływ na dyrektorskie nominacje w teatrach od czasów centralizacji.

Mimo że minister w rozporządzeniu dookreśla organizację i tryb przeprowadzania konkursu ${ }^{43}$ (sposób powoływania członków komisji konkursowej, zadania komisji oraz procedury „zapewniające ocenę kwalifikacji kandydatów”), to na poziomie ustawy jednak zapisano skład komisji: 1) trzech przedstawicieli organizatora, 2) dwóch przedstawicieli ministra kultury, 3) dwóch przedstawicieli zakładowych organizacji związkowych, działających w tej instytucji kultury (lub członków załogi, jeśli związku nie ma), 4) dwóch przedstawicieli stowarzyszeń zawodowych lub twórczych właściwych ze względu na zakres działania tej instytucji kultury.

W roku 2011 Sejm dokonał dużej nowelizacji ustawy. Propozycja zmian powstała na fali środowiskowych debat po Kongresie Kultury Polskiej w 2009 roku. Podczas Forum Polskiego Teatru minister w Kancelarii Premiera, Michał Boni zadeklarował pomoc przy wdrożeniu zmian przygotowanych przez największe organizacje teatralne (ZASP, SDT, UPT). I zamysł się powiódł.

${ }^{41}$ A. Lis, Teatry dramatyczne $w$ czasie przemian $w$ latach 1989-1997, s. 62.

${ }^{42}$ Ustawa z dnia 18 grudnia 2003 r. o zmianie ustawy o organizowaniu i prowadzeniu działalności kulturalnej, Dz.U. 2004 nr 11 poz. 96.

${ }^{43}$ Rozporządzenie Ministra Kultury z dnia 30 czerwca 2004 r. w sprawie organizacji i trybu przeprowadzania konkursu na kandydata na stanowisko dyrektora instytucji kultury, Dz.U. 2004 nr 154 poz. 1629. 
Nowelizacja wprowadziła kategorię instytucji artystycznych, którymi są instytucje kultury

[...] powołane do prowadzenia działalności artystycznej w dziedzinie teatru, muzyki, tańca, z udziałem twórców i wykonawców, w szczególności: teatry, filharmonie, opery, operetki, orkiestry symfoniczne i kameralne, zespoły pieśni i tańca oraz zespoły chóralne.

Działalność instytucji artystycznych organizowana jest na podstawie - tu kolejne nowe pojęcie - sezonu artystycznego, od 1 września do 31 sierpnia roku następnego. $\mathrm{Na}$ ten okres ustala się plany repertuarowe. Określono czas trwania kadencji dyrektora - od trzech do pięciu sezonów, jednak nie ograniczono liczby kadencji.

Dookreślono tryb i warunki udzielania zgody na powołanie dyrektora bez konkursu. Co ważne, w przypadku powołania tego samego dyrektora na kolejną kadencję nie jest już wymagana zgoda ministra, a jedynie jego opinia ${ }^{44}$. Wzajemne relacje organizatora i dyrektora reguluje umowa - zawierana przed powołaniem i będąca jego warunkiem - w której określone są warunki organizacyjno-finansowe działalności instytucji kultury oraz program jej działania. Na nowo też opisano warunki powierzenia zarządzania instytucji kultury - teraz ma się ono odbywać na podstawie Prawa zamówień publicznych.

Z punktu widzenia dyrektorów poważnym mankamentem nowelizacji było utrącenie przez PSL zapisów o umowach jednosezonowych i wycięcie z projektu szczegółowych rozwiązań dotyczących funkcjonowania teatrów. Jednak mimo to udało się podstawowe kwestie w miarę uporządkować. Niech wyznacznikiem sukcesu dyrektorów teatrów będzie to, że organizatorowi obecnie bardzo trudno odwołać dyrektora przed końcem kadencji.

Przez te wszystkie lata nie zmienił się tylko artykuł 17: niezmiennie dyrektor zarządza instytucją i reprezentuje ją na zewnątrz.

\section{Podsumowanie}

Ponad pięćdziesiąt lat zajęło normowanie statusu dyrektora teatru, tak by prócz obowiązków nadać tej funkcji pewne prawa wobec (niekiedy) arbitralnych decyzji organizatora instytucji. Kłopoty z uzgodnieniem tej kwestii w PRL stają się ilustracją szerszej kwestii - sposobu sprawowania władzy, kiedy to wiele problemów rozwiązywano nieformalnie, a brak konkretnych rozwiązań dawał swobodę działania politykom i urzędnikom.

Dopiero w wolnej Polsce środowiskowe starania znalazły większe zrozumienie u decydentów. Ustrój demokratyczny wymuszał tworzenie przejrzystych procedur: zatem stopniowo coraz bardziej szczegółowo opracowano zagadnienia dotyczące dyrektorów instytucji kultury: sposób powołania i odwołania, terminy kadencji, relacje

${ }^{44} \mathrm{~W}$ przypadku odwołania dyrektora też potrzebna jest tylko opinia ministra. 
z organizatorem i MKiDN. Praca dyrektora nabrała pewnej stabilizacji. Zwiększył się też wpływ ministra kultury na nominacje dyrektorskie.

Wciąż „momentem krytycznym” jest tryb powołania nowego dyrektora. Samorządowcy mają wybór - albo powołać bez konkursu, ryzykując brak zgody ministra, ale skorzystać z procedury konkursowej, która uwalnia od wymogu zgody. Współczesna praktyka pokazuje, że odpowiednio dobrany skład komisji może zapewnić organizatorowi wyłonienie kandydata, na którego zdecydował się jeszcze przed konkursem. Wszystko przy zachowaniu demokratycznej procedury. Nie można zapomnieć o dodatkowym aspekcie tego problemu, na który już lata temu zwracał uwagę Andrzej Lis: „najistotniejszą wadą takiego systemu wyłaniania dyrektorów wydaje się to, iż nie stają do owych konkursów najlepsi, najzdolniejsi i przede wszystkim najmłodsi" ${ }^{45}$.

W ostatnich latach podjęto próbę unormowania obyczajów związanych z powoływaniem dyrektora teatru. W roku 2014 Zenon Butkiewicz, ówczesny dyrektor Departamentu Narodowych Instytucji Kultury, uruchomił prace nad Katalogiem dobrych praktyk $k^{46}$. W 2016 roku już na forum środowiskowej grupy roboczej dokument zyskał ostateczny kształt oraz akceptację dwóch komisji kultury: Związku Miast Polskich i Związku Województw RP. Choć Katalog jedynie sugeruje, jak przeprowadzić zmianę kierownictwa teatru z poszanowaniem charakteru instytucji, to codzienność życia teatralnego w Polsce pokazuje, że przed tym dokumentem długa droga. Czas pokaże, czy podobna do tej, którą przechodził Status dyrektora teatru?

Zmaganie ludzi teatru z ludźmi władzy o zakres praw i obowiązków to trwała, niezależna od ustroju politycznego i gospodarczego cecha funkcjonowania teatru publicznego w Polsce - trwała, bo dotycząca kwestii podstawowej dla obu stron: zakresu władzy.

\section{Bibliografia}

Biernat S., Położenie prawne instytucji artystycznych, „Państwo i Prawo” 1985, nr 7-8, s. 54-66. Butkiewicz Z., List do redaktora naczelnego, „Teatr” 2016, nr 12.

Cehl L., Myśmy wszystko zapomnieli, „Scena” 2001, nr 3.

Csató E., Dlużej zwlekać nie podobna, wstępniak, „Teatr” 1958, nr 24.

Csató E., O status dyrektora teatru, wstępniak, „Teatr” 1959, nr 21.

Greń Z., Taki nam się snuje dramat... Szkice z teatru 1971-1976, Kraków 1978.

Kunc W., Organizacja i zarządzanie teatrem w Polsce na przykładzie Opery na Zamku [w:] Międzynarodowa Konferencja „,Teatry w Europie”. Organizacja, finansowanie i wspótpraca transgraniczna, Szczecin 2003, s. 47-54.

Lis A., Teatry dramatyczne w czasie przemian w latach 1989-1997 [w:] T. Kostyrko (red.), Kultura Polska 1989-1997. Raport, Warszawa 1997, s. 55-70.

${ }^{45}$ A. Lis, Teatry dramatyczne w czasie przemian w latach 1989-1997, s. 62.

46 Z. Butkiewicz, List do redaktora naczelnego, „Teatr” 2016, nr 12. 
Markow R., Po co dyrektorowi teatru kontrakt menadżerski? [w:] II Międzynarodowa Konferencja „Teatry w Europie”. Teatr - otoczenie społeczne, prawne i finansowe, Szczecin 2004, s. 139 151.

Rosenberg M., Działalność sekcji branżowych NSZZ „, Solidarność” w latach 1980-1981 na przykładzie Krajowej Komisji Porozumiewawczej NSZZ „Solidarnośc”” Pracowników Teatru, „Polska 1944/45-1989” 2016, nr 14.

Sokołowski J., Jedna sprawa, „Teatr” 1981, nr 6.

Syczewski A., Dziś i jutro polskiego teatru, „Życie Literackie” 1977, nr 22.

Zarys nowego modelu życia teatralnego. Projekt, 1982, Archiwum MKiDN, syg. 1243/17.

\section{Dokumenty archiwalne}

Englert M., Uwagi do projektu ustawy o działalności kulturalnej, Pracownia Dokumentacji Teatru Instytutu Teatralnego - Archiwum Jana Siekiery, dalej PDT - AJS.

List podsekretarza stanu w Ministerstwie Kultury i Sztuki z dnia 7 I 1980 r., 1.dz. V BOZ/58/79 do Gustawa Holoubka, prezesa Zarządu Głównego SPATiF, teczka Mianowania na stanowiska dyrektorów i kierowników artystycznych. Korespondencja 1980-1981, Archiwum ZASP 3/177, dalej AZASP.

Odpis pisma 1596/58 Prezydium ZASP do CZT i CZIM z dnia 31 V 1958 roku, AZASP 3/170.

Odpis pism 3459/60 z dnia 28 VI 1960 r. i 3710/60 z dnia 13 VII 1960 r. do dyrektora Zespołu ds. Teatru MKiS, AZASP 3/170.

Pismo dyrektora Zespołu ds. Teatru do Prezydium SPATiF z dnia 19 VII 1960 r., AZASP 3/170.

Protokół posiedzenia Grupy Dyrektorów Teatrów ZASP w dniu 8 I 1962 r., teczka Protokoły z narad dyrektorów teatrów 1958-1963, AZASP, syg. 3/124.

Protokół z zebrania Prezydium Grupy Dyrektorów w dniu 17 I 1966 r., teczka Protokoły z Zebrań Grupy Kierowników Teatrów 1964-1965, AZASP syg. 3/125.

Protokoły Prezydium ZG ZASP 1971-1972 (teczka), AZASP 3/75.

Raport. Informacja o stanie teatrów miejskich, Wydział Kultury i Sztuki Biura Zarządu m. st. Warszawy, marzec 1995.

Wyciąg z protokołu posiedzenia Prezydium ZG SPATiF z 10 VI 1974, AZASP syg. 9/154.

Status Dyrektora Teatru, kierownika literackiego i reżysera 1975-1976 (teczka), AZASP 3/44.

Status dyrektora teatru, 1977, AJS - PDT IT.

Stenogram z narady dyrektorów teatrów 5-6 maja 1958 r., AZASP 3/169, s. 71-72. 